\title{
A Note on the Author
}

L.M. Montgomery is now widely recognized as a major twentieth-century author, one whose bestselling books remain hugely popular and influential all over the world more than three-quarters of a century after her death. Born in Clifton (now New London), Prince Edward Island, in I 874, into a family whose ancestors had immigrated to Canada from Scotland and England, she was raised in nearby Cavendish by her maternal grandparents following the death of her mother and spent a year during her adolescence with her father and his new family in Saskatchewan. Raised in a household that distrusted novels but prized poetry and oral storytelling, she began to write during childhood, although few examples of her juvenilia survive. She received a teaching certificate from Prince of Wales College (Charlottetown) and, after one year of teaching school, took undergraduate courses in English literature for a year at Dalhousie University (Halifax), but she did not have the financial resources to complete her degree. During this time, she began publishing essays, short fiction, and poems in North American periodicals. In I 898, after two more years of teaching school, she returned to Cavendish to take care of her widowed grandmother and to write full-time, soon earning more from her pen than she had teaching school. With the exception of a nine-month stint on the staff of the Halifax Daily Echo, where her duties included writing a weekly column entitled "Around the Table," Montgomery remained in Cavendish until I9I I, when the death of her grandmother freed her to marry a Presbyterian minister. After a honeymoon in England and Scotland, she and her husband moved to 
southern Ontario, where she divided her time between writing, motherhood, and the responsibilities that came with her position as a minister's wife.

Her first novel, Anne of Green Gables (1908), the benchmark against which her remaining body of work is measured, was followed by twenty-three additional books, including ten featuring Anne Shirley: Anne of Avonlea (1909), Chronicles of Avonlea (19I2), Anne of the Island (I9I5), Anne's House of Dreams (1917), Rainbow Valley (1919), Further Chronicles of Avonlea (1920), Rilla of Ingleside (1921), Anne of Windy Poplars (1936), Anne of Ingleside (1939), and The Blythes Are Quoted, completed shortly before her death but not published in its entirety until 2009. During her distinguished career, she was made a Fellow of the British Royal Society of Arts, was named one of the twelve greatest women in Canada by the Toronto Star, and became an Officer of the Order of the British Empire. When she died in I942, apparently by her own hand, her obituary in the Globe and Mail declared that her body of work "showed no lessening of that freshness and simplicity of style that characterized Anne of Green Gables." Since her death, several collections of her periodical pieces have been published, as have more than a dozen volumes of her journals, letters, essays, and scrapbooks. Ontario and Prince Edward Island are home to many tourist sites and archival collections devoted to her, and her books continue to be adapted for stage and screen. 